\title{
A CLINICAL ASSESSMENT OF ANTIRETROVIRAL-TREATED PATIENTS REFERRED FROM THE PRIVATE SECTOR TO THE SOUTH AFRICAN GOVERNMENT ANTIRETROVIRAL (ARV) PROGRAMME: A RETROSPECTIVE ANALYSIS
}

Rianna Gounden, MMedSc (Clin Pharmacol)

Pharmacist, Department of Health

Objectives. A comparison of the effects of highly active antiretroviral therapy (HAART) on the immunological, virological and clinical status of two groups of patients in the South African government antiretroviral (ARV) programme in KwaZulu-Natal, viz. patients previously treated with ARVs in the private sector and then entering the government programme (private group), and ARV-naïve patients entering the programme directly (government group).

Methods. A retrospective, cohort study was performed by reviewing records of 58 former private sector patients and 98 patients initiated on ARV treatment in the government sector. Treatment regimens, CD4 cell counts, viral loads and regimen modifications were analysed.

Results. The study found that use of various classes of ARV drugs varied between the private sector and the government sector. Median distribution of CD4 cell count increased from 158.5 to $419 \mathrm{cells} / \mu \mathrm{l}$ for the private group (42 patients (72.4\%)) and from 101 to 358 cells/ul for the government group (95 patients (96.9\%)), over an average time span ranging from 29 to 30 months. Median viral load decreased in the private group (29 patients $(50 \%))$ and the government group (66 patients $(67.3 \%))$ to approximately $3.22 \mathrm{log}$ copies $/ \mathrm{ml}(25 \mathrm{copies} / \mathrm{ml})$ over an average time span ranging from 27 to 29 months. The rate of change of CD4 cell count $(p=0.47)$ and viral load $(p=0.097)$ between the two groups was not significantly different.

Conclusion. This study showed that even for patients with prior experience with ARVs, virological and immunological success is still achievable with the use of standardised HAART regimens in the government programme.

The South African government antiretroviral (ARV) programme was designed as a structured, regulated programme utilising standardised treatment guidelines and multidisciplinary concepts. A major reason for these protocols was achieving maximal and durable suppression of viral replication and stemming development of ARV resistance..$^{1-3}$ In contrast, the private sector is not regulated by such controls. Unregulation over prescribing practices has resulted in use of various treatment combinations. Inevitably, some private patients have entered the government programme.

Private sector ARV provision appears to have been overlooked. No formal study has been conducted in South Africa comparing the two sectors with regard to treatment provision to HIV-infected patients. The present study defined a subgroup within the government programme, viz. patients previously treated in the private sector, and compared them with never-treated patients commencing ARVs. Immunological, virological and clinical parameters were used as a means of comparative assessment.

Issues raised by this study were lack of policies regulating private sector treatment, treating ARV-experienced patients, and development of drug toxicity.

\section{METHODS}

The retrospective cohort study was performed at HIV clinics at Addington and King Edward VIII hospitals in KwaZulu-Natal, from 2004 until April 2008. Follow-up time ranged from 24 to 41 months. A sample size of 90 subjects was targeted, comprising 30 index subjects and 60 control subjects.

The index subjects (private group) were patients previously on ART in the private sector who entered the government programme, and the control subjects 
(government group) were patients who were initiated on ART in the government sector. Both index and control subjects met inclusion criteria.

Inclusion criteria:

- adult patients ( over 18 years)

- for CD4 count and viral load analysis, at least three sets of measurements were required

- all patients regarded as control subjects (government group) had to be ARV naïve, i.e. no prior exposure to antiretrovirals.

\section{Exclusion criterion:}

- trial patients, i.e. initiated on ART as clinical trial participants and then entering the programme.

In the study, for every index subject identified, the next 2 subjects (consecutive numbering hospital recordkeeping system) were selected as control subjects. The rationale for this was that the time frame for both indexes and controls would correlate closely.

Measurements analysed were:

- baseline patient characteristics

- CD4 cell count

- HIV plasma RNA levels

- comparison of regimen modifications and reasons for these

a death.

The study was designed with a statistical power of $80 \%$, with a sample size of 30 index subjects and 60 controls deemed sufficient to detect an effect size of 1.5 between the two groups. The a-level of significance was specified at 0.05 , with a confidence level of 0.95 .

Following commencement of government ARVs, measurements were recorded at baseline and subsequent intervals of $2-13,14-25$ and $26-41$ months. In intervals containing more than one measurement, the average was taken. All data were analysed using Stata software (Windows).

The plotting of line graphs comparing CD4 cell counts and viral load changes only included patients with data in all four time intervals. Patients presenting with baseline and last recorded readings were included in rate of change and distribution analyses.

Measurements of rates of change for CD4 counts and viral loads were taken as functions of the difference between the baseline and latest measurements and follow-up time. The two-sample Wilcoxon rank-sum (Mann-Whitney) test was used for analysis of rates of change for CD4 and viral load. Distribution of CD4 cell counts and viral loads were calculated using median values and interquartile ranges (IQRs).

\section{RESULTS}

Patient baseline characteristics are set out in Table I.

\section{COMPARING ANTIRETROVIRAL USE IN THE PRIVATE SECTOR VERSUS THE GOVERNMENT SECTOR}

During this study, first-line regimens in the government sector consisted of lamivudine, stavudine and efavirenz/ nevirapine. ${ }^{4}$ The second-line regimen was zidovudine, didanosine and lopinavir/ritanovir. ${ }^{4}$

Figs 1 - 3 illustrate percentages of private sector patients on individual ARVs before entry into government hospitals, and percentages of all patients studied (both private and government initiates) on individual ARVs in the government programme.

Lamivudine formed the backbone of first-line regimens in the government sector $(98 \%)(N=156)$, compared with $62 \%(N=58)$ in the private sector. Zidovudine was

\begin{tabular}{|c|c|c|c|}
\hline Characteristics ( $N=156)$ & Private group $(N=58)$ & Government group $(N=98)$ & Total \\
\hline Females & 67 & 80 & 75 \\
\hline Males & 33 & 20 & 25 \\
\hline Black & 75 & 96 & 83 \\
\hline Coloured & 9 & 1 & 3 \\
\hline Indian & 12 & 1 & 4 \\
\hline White & 4 & 1 & 2 \\
\hline \multicolumn{4}{|l|}{ WHO staging (baseline) } \\
\hline Stage 1 & 33 & 18 & 19 \\
\hline Stage 2 & 12 & 27 & 19 \\
\hline Stage 3 & 33 & 46 & 34 \\
\hline Stage 4 & 19 & 10 & 10 \\
\hline \multicolumn{4}{|l|}{ Baseline } \\
\hline Opportunistic infections & 32 & 44 & 40 \\
\hline Oesophageal candiasis & 2 & 9 & 6 \\
\hline Tuberculosis & 12 & 17 & 16 \\
\hline Pneumocystis carinii pneumonia & - & 1 & 1 \\
\hline Toxoplasmosis & 3 & 1 & 2 \\
\hline AIDS-related wasting syndrome & 7 & 1 & 3 \\
\hline
\end{tabular}




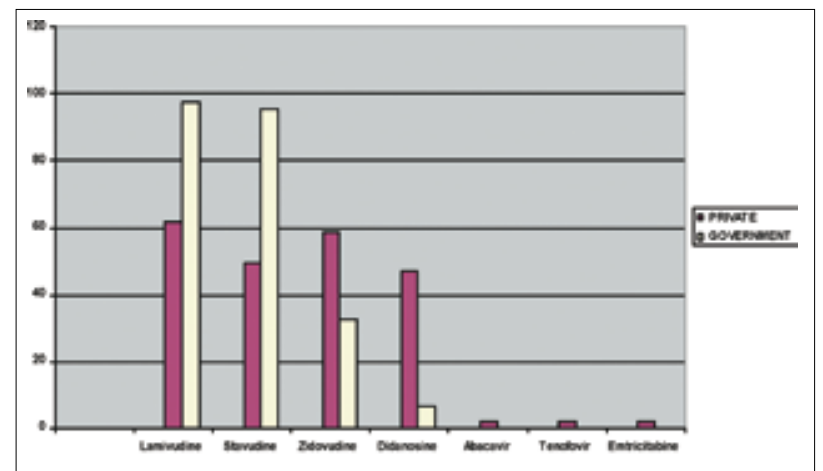

Fig. 1. Nucleoside reverse transcriptase inhibitor use by patients in the private sector (\%) compared with combined use by all patients in the government programme (\%).

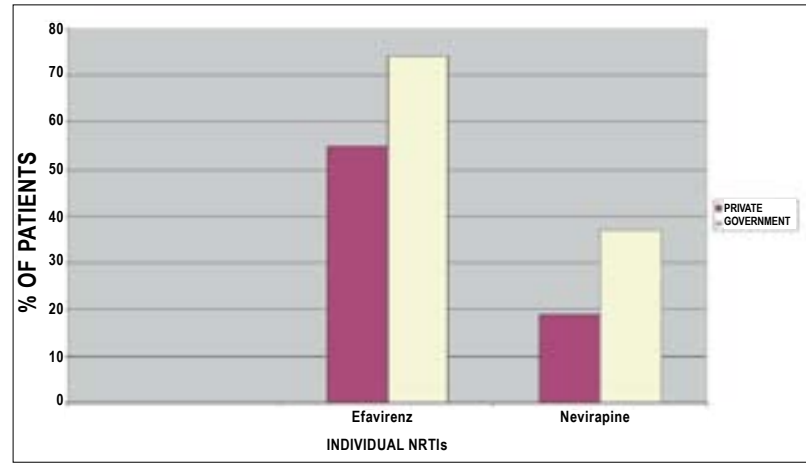

Fig. 2. Non-nucleoside reverse transcriptase inhibitor use by patients in the private sector (\%) compared with combined use by all patients in the government programme (\%).

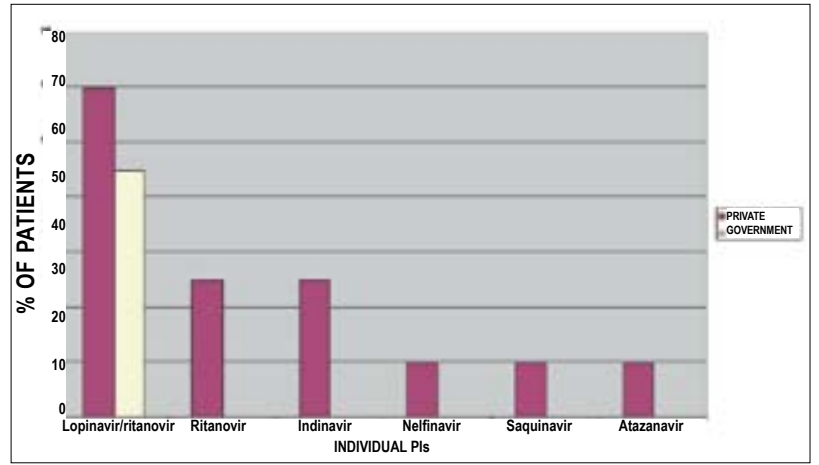

Fig. 3. Protease inhibitor use by patients in the private sector (\%) compared with combined use by all patients in the government programme (\%).

the second most frequently used nucleoside reverse transcriptase inhibitor (NRTI) (59\%) (N=58) among private patients.

Stavudine was used in regimens of $96 \%$ of all government patients compared with $50 \%$ of private sector patients. Among private patients, $47 \%$ had previous experience with didanosine compared with $7 \%$ of all government patients. Abacavir and tenofovir constituted the private regimens of $2 \%$ of patients.

Efavirenz was commonly used in both the private (55\%) and government $(74 \%)$ sectors. In the private sector, $19 \%$ had experience with nevirapine, compared with $37 \%$ in the government sector.

In the private sector $28 \%$ of patients had protease inhibitor (PI)-containing regimens. In many cases,
PIs constituted part of first-line treatment. The most commonly used PI was lopinavir/ritanovir (used by $12 \%$ of patients in the private sector). Lopinavir/ritanovir was used in $9 \%$ of government sector regimens.

Ritanovir was used individually in $5 \%$ of private sector regimens. Indinavir and saquinavir, and nelfinavir and atazanvir, were used in $5 \%$ and $2 \%$, respectively, of private sector regimens.

In the private sector sample, $69 \%$ began treatment privately in 2003 or 2004 . Twenty-five per cent of these patients were placed on dual therapy at some stage during private treatment. The majority of these regimens included single-class drugs, viz. NRTIs. On commencing government ARVs, the majority of these patients (82.7\%) were placed on first-line regimens. The remainder were either placed on regimen 2 or remained on their private sector regimen.

\section{COMPARING CD4 CELL COUNT CHANGES IN THE PRIVATE GROUP VERSUS THE GOVERNMENT GROUP}

Twenty-six private group patients $(44.8 \%)$ and 63 government group patients $(64.3 \%)$ presented with baseline median CD4 counts of 156 cells/ $\mu$ l and 106 cells/ $\mu \mathrm{l}$, respectively (Fig. 4). Commencement of ARVs in the government group resulted in an initial higher rate of increase in CD4 count. This subsequently diminished after 12 months, while the private group's median count increased steadily. The last recorded median CD4 counts were $419 \mathrm{cells} / \mu \mathrm{l}$ for the private group and $360 \mathrm{cells} / \mu \mathrm{l}$ for the government group.

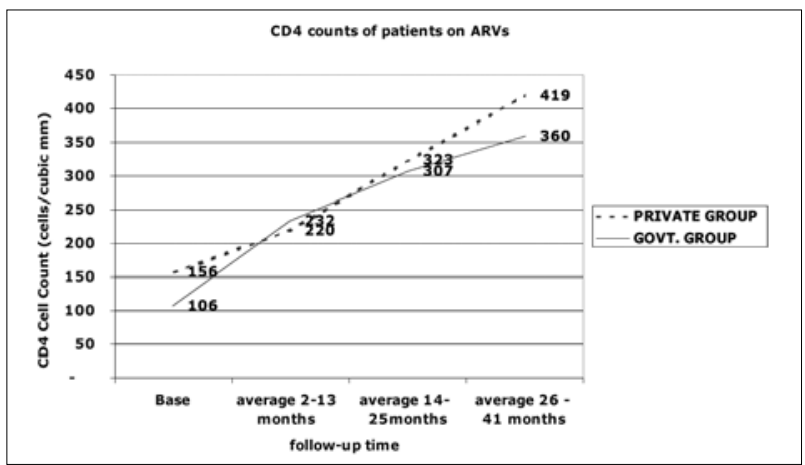

Fig. 4. Comparison of change in CD4 cell count (cells/ $\mu$ l) in the private group versus the government group.

\section{CD4 CELL COUNT DISTRIBUTION}

Both groups displayed variable CD4 count distribution, so median values and IQRs were calculated. Distribution of CD4 counts (cells/ $\mu$ l) at baseline showed:

- private group $(N=42)$ : median/(IQR) - 158.5 (111 325)

- government group ( $N=95)$ : median/IQR - 101 (33 153)

- both groups ( $N=137)$ : median/IQR - 122( $46-175)$.

Distribution of last recorded CD4 counts (cells/ $\mu$ l) showed:

- private group ( $N=42)$ : median/IQR - 419 (231 - 706)

- government group ( $N=95)$ : median/IQR - 358 (263 - 506)

both groups $(N=137)$ : median/IQR - 368 (254 - 538). 
The private group's median CD4 count increased from 158.5 cells $/ \mu$ lo 419 cells/ $\mu$ l over an average of 29 months. In the government group, the baseline median (101 cells $/ \mu \mathrm{l})$ reached $358 \mathrm{cells} / \mu \mathrm{l}$ over an average of 30 months.

The majority of observations (75\%) in the private group and government group recorded baseline counts of $325 \mathrm{cells} / \mu \mathrm{l}$ and $153 \mathrm{cells} / \mu \mathrm{l}$, respectively. These values increased substantially after commencement of government ARVs. The last recorded readings indicated that $75 \%$ of patients in the private and government group had attained median CD4 counts of 706 cells/ $\mu$ land 506 cells/ $\mu$ l, respectively.

\section{AVERAGE RATE OF CHANGE OF CD4 CELL COUNT}

The average rates of change of the $\mathrm{CD} 4$ cell count in the government group and the private group were 9.74 cells/ $\mu \mathrm{l}$ and $8.81 \mathrm{cells} / \mu \mathrm{l}$ per month, respectively.

The two-sample Wilcoxon rank-sum (Mann-Whitney) test compared rate of change in CD4 count between 42 patients in the private group (72.4\%) and 95 patients in the government group (96.9\%). Average followup time for the private group and government group was 29 months and 30 months, respectively. Using a significance level of $a=0.05$, the test concluded that there was no significant difference in rate of change of CD4 count $(p=0.47)$ between the two groups.

\section{COMPARING VIRAL LOAD CHANGE IN THE PRIVATE GROUP VERSUS THE GOVERNMENT GROUP}

In the government group 43 patients (43.9\%) presented with a median baseline viral load of 10.61 log copies/ $\mathrm{ml}$ (40 000 copies/ml) (Fig. 5), compared with $7.82 \mathrm{log}$ copies $/ \mathrm{ml}$ (almost 2500 copies $/ \mathrm{ml}$ ) in 17 patients in the private group $(29.3 \%)$. Commencement of government ARVs achieved rapid viral load suppression in the first 8 months in the government group, compared with the private group. However, both groups eventually reached log 3.22 copies/ml (<25 copies/ml - undetectable levels).

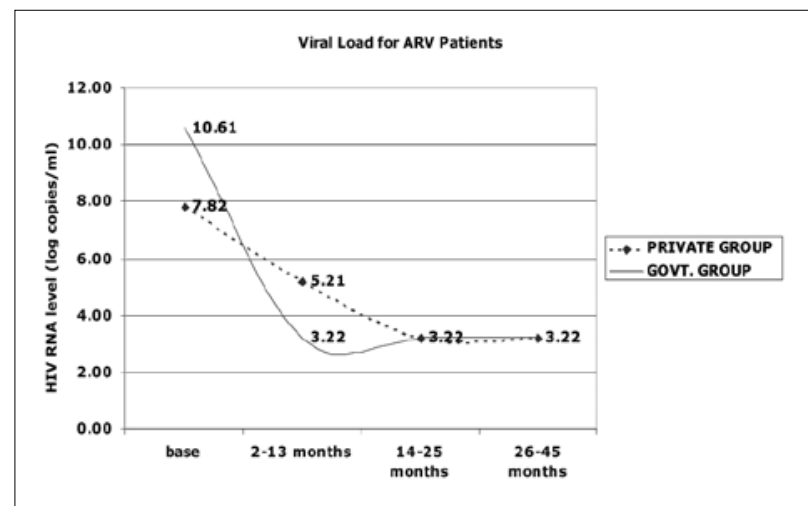

Fig. 5. Comparison of change in viral load (log copies/ml) in the private group versus the government group.

VIRAL LOAD VALUE DISTRIBUTION

Distribution of viral load values was variable. Distribution of viral load values (log copies $/ \mathrm{ml}$ ) at baseline showed: - private group $(N=29)$ : median/IQR - 8.88461 (6.461468 - 11.39275) government group $(N=66)$ : median/IQR -10.7425 (9.148465 - 12.10071)

- both groups $(N=95)$ : median/IQR - 10.40426 $(8.006368-11.98293)$.

Distribution of last recorded median viral load values (log copies/ml) showed:

- private group $(N=29)$ : median/IQR - 3.218876 $(3.218876-5.703783)$

- government group $(N=66)$ : median/IQR - 3.218876 (3.218876 - 3.218876)

- both groups $(N=95)$ : median/IQR - 3.218876 (3.218876-3.218876).

In the private group, median viral load decreased from 8.88461 log copies $/ \mathrm{ml}$ (7200 copies $/ \mathrm{ml}$ ) to 3.218876 log copies/ml (<25 copies/ml - undetectable levels), over an average of 27 months. The government group's median viral load decreased from 10.7425 log copies $/ \mathrm{ml}$ (>46 000 copies $/ \mathrm{ml}$ ) to undetectable levels, over an average of 29 months.

Seventy-five per cent of patients in the private group and government group presented with baseline viral load levels of $11.39275 \mathrm{log}$ copies/ml (>88 000 copies/ $\mathrm{ml}$ ) and $12.10071 \mathrm{log}$ copies $/ \mathrm{ml}$ (180 000 copies $/ \mathrm{ml}$ ), respectively. Viral load decreased after commencement of government ARVs. The private group and the government group showed last recorded readings of 5.703783 log copies $/ \mathrm{ml}$ (300 copies $/ \mathrm{ml}$ ) and undetectable levels, respectively.

\section{AVERAGE RATE OF CHANGE OF VIRAL LOAD}

The average rates of change in viral load for the government group and the private group were 0.345804252 log copies $/ \mathrm{ml}(1.41$ copies $/ \mathrm{ml})$ per month and 0.328619966 log copies $/ \mathrm{ml}$ (1.39 copies $/ \mathrm{ml}$ ) per month, respectively.

The two-sample Wilcoxon rank-sum (Mann-Whitney) test compared rates of change in viral load between 29 patients in the private group (50\%) and 66 patients in the government group (67.3\%). Average follow-up times for the private group and the government group were 27 months and 29 months, respectively. Using a significance level of $a=0.05$, the test concluded that there was no significant difference in rate of change of viral load $(p=0.097)$ between the two groups.

\section{REGIMEN MODIFICATION AND CAUSES}

In the private group, $46.5 \%$ of regimen modifications occurred after commencing government ARVs, while the government group recorded $45.9 \%$. Major causes for modifications in both groups were lactic acidosis, peripheral neuropathy, tuberculosis, lipodystrophy and virological failure.

In the private group and the government group, $12 \%$ and $7 \%$ of patients, respectively, experienced symptoms of lactic acidosis or hyperlactataemia. In all episodes stavudine was changed to zidovudine. Ninety per cent of patients (both groups) who experienced symptoms of 
hyperlactataemia were female. Median ages recorded in the private group and the government group were 34 and 40 years, respectively.

Nine per cent of private patients and $5 \%$ of government patients were diagnosed with lipodystrophy. In all patients stavudine was implicated and replaced with zidovudine. Overall, $80 \%$ of these patients were female and the median age for both groups was 40 years. The baseline median CD4 counts for patients diagnosed with lipodystrophy in the private group (249.5 cells/ $\mu$ l) and the government group (194 cells/ $\mu$ l) correlated with observations of baseline CD4 counts below 350 cells/ $\mu$ l being a risk factor for development of lipodystrophy. ${ }^{5}$

Seven per cent of the private group and $19 \%$ of the government group experienced peripheral neuropathy. Stavudine was implicated in most cases and replaced with zidovudine.

In the private group and the government group, 3\% and $5 \%$ of patients, respectively, were co-infected with tuberculosis while on government ARVs, necessitating regimen modification.

The second most common factor for regimen changes in the private group was virological failure. Approximately $10.3 \%$ of private patients developed virological failure. In the government group only 1 patient developed virological failure.

Approximately $5.2 \%$ of private patients were lost to follow-up, probably due to death. This assumption was based on their last recorded CD4 counts (low). However, confirmation of death was incomplete and presumed from loss of follow-up data. No patient deaths were recorded in the government group.

\section{DISCUSSION AND CONCLUSION}

This study hypothesised that due to prior ARV use, and in many instances use of sub-therapeutic regimens and treatment interruption, treatment in the private group would not be as successful in terms of immunological, virological and clinical improvement as in the ARV-naïve government group.

However, it was observed that with implementation of standardised highly active antiretroviral therapy (HAART) regimens for the private group, there was immunological and virological improvement. On commencement of government HAART, there was no significant difference in rate of change of CD4 count $(p=0.47)$ or viral load $(p=0.097)$ between the two groups.

However, while both groups showed decreased viral loads, an important point in terms of distribution analysis was that over 27 months $75 \%$ of patients in the private group recorded a median viral load of 300 copies $/ \mathrm{ml}$, while in the government group the same majority recorded undetectable levels (<25 copies $/ \mathrm{ml}$ ). This implies that a better pharmacological response to HAART was possibly achieved in the ARV-naive group compared with the previously treated group. This assumption is further enhanced by higher percentages of virological failure (10.3\% v. 1\%) and death (presumed) $(5.2 \%$ v. nil) occurring in the private group.

Usage of various ARV classes varied between the two sectors. During this study, drugs reserved as second line in the government sector (didanosine and zidovudine) often formed part of first-line regimens in the private sector. The only PI available in the government sector at the time was lopinavir/ritanovir, which was used by $9 \%$ of patients as part of second-line treatment. In the private sector $28 \%$ of patients had $\mathrm{Pl}$-containing regimens, often as part of first-line treatment. A quarter of private sector patients studied were placed on dual therapy (associated with partial viral suppression ${ }^{2}$ ) at some stage during private treatment. This may be attributed to non-standardised prescribing trends in the private sector. Studies have found that prescribing practices of physicians may be influenced by interactions with pharmaceutical representatives regarding awareness, preference and rapid prescribing of new drugs. ${ }^{6}$

In both groups, $90 \%$ of patients with hyperlactataemia were female, corresponding with studies showing female gender to be a prognostic factor. ${ }^{7}$ The higher percentage of lipodystrophy in the private group corresponds with observations of prior ARV experience being a risk factor. ${ }^{5}$ Peripheral neuropathy was the most frequently observed toxicity in the government group and was linked to stavudine use.

This study has shown that even with previous ARV exposure, immunological and virological success is achievable. Potent standardised regimens, counselling, regular follow-up and management of side-effects are essential. Overall the success achieved in both groups may be attributed to implementation of standardised treatment guidelines and multidisciplinary approach of the government programme. The private sector should seek to be guided by the same approach.

The above was submitted as part of the requirements for a Masters in Medical Science (Clinical Pharmacology), supervisor Professor Viren Rambiritch, PhD. The degree was awarded cum laude by the University of KwaZuluNatal on 24 April 2009.

Ethics approval was obtained from the University of KZN and the KZN Department of Health. There was no conflict of interest or competing interests.

\section{REFERENCES}

1. World Health Organization (WHO). Antiretroviral Therapy for HIV Infection in Adults and Adolescents: Recommendations for a Public Health Approach - 2006. Geneva: WHO, 2006. http:// www.who.int/hiv/pub/ guidelines/artadultguidelines.pdf (accessed 1 October 2008)

2. Dolin R, Masur H, Saag MS. AIDS Therapy. New York: Elsevier Science, 2003.

3. Shaefer M. Abacavir/lamivudine/zidovudine continues to be a valid and useful antiretroviral regimen. Ann Pharmacother 2004;38:1314-1316.

4. South African Department of Health. National Antiretroviral Treatment Guidelines. Pretoria: Government Printer, 2004.

5. Baril J-G, Junod P, Leblanc R, et al. HIV-associated lipodystrophy syndrome: A review of clinical aspects. Canadian Journal of Infectious Diseases and Medical Microbiology 2005;16(4):233-243.

6. Wazana A. Physicians and the pharmaceutical industry: Is a gift ever just a gift? JAMA 2000;283:373-380

7. Fabian J, Venter WDF, Mkhabela L, Levin JB, Baker L, Naicker S. Symptomatic hyperlactataemia in adults on antiretroviral therapy: A single-centre experience. $S$ Afr Med J 2008;98(10):795-800. 